\title{
Development of Sustainable and Functional Fabrics from Recycled and Nanocomposite Polyester Fibers
}

\author{
Solomon Addis $\left(\mathbb{D},{ }^{1}\right.$ Hermela Ejegu $\left(\mathbb{D},{ }^{2}\right.$ Messay Dubale $\left(\mathbb{D},{ }^{1}\right.$ and Wondwossen Mamuye ${ }^{1}{ }^{1}$ \\ ${ }^{1}$ Ethiopian Textile Industry Development Institute (ETIDI), Addis Ababa, Ethiopia \\ ${ }^{2}$ Department of Textile Engineering, Dire Dawa University Institute of Technology, Dire Dawa, Ethiopia \\ Correspondence should be addressed to Solomon Addis; mitkuadd@gmail.com
}

Received 4 August 2021; Revised 27 September 2021; Accepted 3 November 2021; Published 12 November 2021

Academic Editor: Lijing Wang

Copyright (c) 2021 Solomon Addis et al. This is an open access article distributed under the Creative Commons Attribution License, which permits unrestricted use, distribution, and reproduction in any medium, provided the original work is properly cited.

\begin{abstract}
Antimicrobial knitted and woven fabrics were developed from recycled polyester (PET) and silver nanocomposite (SNC) fibers. Two different fabrics were produced from two different blend proportions of the fibers. The antimicrobial properties of fabrics were tested against those of the S. aureus (Gram-positive) and E. coli (Gram-negative) bacterial natures, and their yarn properties and hand-related characteristics were investigated. The results show uneven fabrics properties such as irregularity in thickness and SNC-recycled PET fiber ratio increase, and the tensile strength decreases while the NEP number increases. This implies that fabrics made from a blend with higher SNC-recycled PET fiber ratios have higher surface roughness levels, higher bending rigidity, and harder texture. As a consequence, the antimicrobial efficiency of the fabrics was improved as the percentage of SNC increased. The recycled PET fiber within the blended yarn shows a good antimicrobial property (above $90 \%$ ) observed in all fabrics. The reduction of bacterial colonies was constantly exceeding $90 \%$ for both E. coli and $S$. aureus in all fabric samples.
\end{abstract}

\section{Introduction}

Recycling is the process of converting waste materials into valuable materials. This is also an alternative way to waste disposal that can save material and help lower greenhouse gas emissions. Besides, it helps us prevent and minimize the waste of potentially useful materials and reduce the consumption of fresh raw materials, thereby reducing energy usage, air pollution, and water pollution [1-3].

PET is a polycrystalline polymer that contains the ester functional group in the main chain and is formed from the esterification of terephthalic acid (TPA) with ethylene glycol (EG) or from the transesterification of dimethyl terephthalate (DMT) with ethylene glycol [4].

A very important use of PET is in the manufacture of packaging for the food industry since it does not have any side effects on human health $[5,6]$. The other driving force for PET recycling is that PET products have a slow rate of natural decomposition or are nondegradable plastic in normal conditions as there is no known organism capable of consuming their relatively large molecules $[7,8]$.

The recycling of PET can be carried out in many ways. The PET recycling methods are categorized as mechanical and chemical methods [10-12]. In the case of the mechanical recycling method (MRM), the waste bottles are usually recycled directly as polymer feed, through grinding, cleaning, separating, dehydrating, drying, and remelting. In such types of recycling methods, cleaning contaminants and controlling moisture content $(0.8 \%)$ are important in order to have good quality recycled chips [13-15], whereas in the case of chemical recycling, depolymerization of PET polymer takes place with different techniques, and the polymer is broken down into monomers and oligomers. The important advantage of chemical recycling is the possibility of getting virgin PET quality, even though the MRM is a cheap and simple process [16].

Using the melt spinning technique, a drawn textured yarn of different counts (PET chips) can be produced from 
both recycling methods $[17,18]$. The recycled PET chips show higher Intrinsic Viscosity (IV) than virgin PET chips because the PET bottles are based on copolyesters, such as isophthalic acid modified PET, which requires higher fiber application $[19,20]$.

Compared with the pure polymer, composite materials may show enhancement in the mechanical, thermal, optical, and physicochemical properties. These enhancements attract the interest of many researchers because they lead to the wider application of many polymers. Composite materials obtained using different polymer matrices have been reported [21].

Nowadays, many composite PET fibers have been researched to improve their thermal and crystalline properties or introduce new functional fabric properties such as electrical conductivity, antibacterial function, and flame redundancy retardant [8]. Among these functional materials, antibacterial materials have recently been in focus. When antibacterial materials are applied to PET fibers, the resultant self-sterilizing fabrics/textiles have the potential benefits of reduced disease transfer among the hospital population, biowarfare protection, and other applications [22, 23].

Silver or silver ions have an extensive surface area than other salts of silver. As a result, it provides better contact with microorganisms and a broad spectrum of antimicrobial activities, and that is why silver or silver ions show efficient antimicrobial properties [24, 25]. Heavy metals are usually toxic and very reactive with proteins due to such properties since they bind protein molecules, the cellular metabolism is inhibited and the microorganism dies [26, 27]. The ability of microorganisms to grow in the presence of metal-containing materials might result from specific mechanisms of resistance. Such mechanisms include alteration of chemical structure and toxicity by changes in the redox state of the metal ions. However, silver is well known as nontoxic in spite of being claimed to kill many different disease organisms and skinfriendly and does not cause skin irritation [28-30].

The SNCs aggregate in the media with a high electrolyte potential, reducing the antibacterial property; some supporting materials such as zeolite, titanium, carbon, ferrites, and polymers are applied to the solution of these nanoparticles with nanocomposite formation. Polyethylene, polydopamine, polyimide, polyvinyl alcohol, and polypyrene polymers have been successfully applied as the supporting compounds [31].

Silver is a safer antimicrobial agent in comparison with some organic antimicrobial agents that have been avoided because of the risk of their harmful effects on the human body [32]. Silver has been described as being "oligodynamic" because of its ability to exert a bactericidal effect on products containing silver, principally due to its antimicrobial activities and low toxicity to human cells. In addition, its therapeutic property has been proven against a broad range of microorganisms, over 650 disease-causing organisms in the body even at low concentrations [33].

Antimicrobials are typically applied to give textiles improved resilience against microorganisms (e.g., preventing the destruction of polymers and discoloration) and increased durability of the textile, leading to a longer lifetime of use [16]. Antimicrobials can also be used to protect textiles against colonization of odor-forming bacteria and may also be applied to textiles to play a role in addressing hygiene in clinical and sensitive environments by minimizing the chances for microbial colonization of textiles and the potential for transfer from fabric surface [34].

The functional properties of textiles can be modified by the addition of nanomaterials that can improve the properties of textiles, such as antibacterial properties, UV protection, abrasion resistance, and hydrophobicity $[35,36]$. Recently, antimicrobial agents that have been used industrially have included quaternary ammonium salts, metal salt solutions, and antibiotics. Unfortunately, some of these agents are toxic or poorly effective, making them unsuitable for application in healthy foods, filters, textiles, and the exclusions of pollution. On the other hand, silver is a nontoxic, nontolerant disinfectant that significantly reduces many bacterial infections [37].

This study aims to produce sustainable antimicrobial fabrics from recycled PET and SNC with different proportion ratios and analyses antimicrobial, physical, and mechanical properties of produced fabrics.

\section{Materials and Methods}

2.1. Materials. Recycled PET and SNC fibers were used to produce antimicrobial fabrics. In order to compare the antimicrobial and physical properties of the produced fabrics, different fiber ratios were chosen. Table 1 gives the details of recycled and nanocomposite fiber blend ratios in the yarn. The linear density and length of SNC and PET fibers are 1.4 dtex and $34 \mathrm{~mm}$, respectively. Single fiber tensile strength (cN/tex) and elongation (\%) of the fibers were tested on Instron 3365 based on ASTM D3822/ D3822M.

\subsection{Methodology}

2.2.1. Yarn Sample Preparation. Firstly, two different blends of yarn were prepared from recycled PET and nanocomposite PET fibers; secondly, two slivers were also produced from blended fibers on a carding machine; thirdly, two rovings from each blend were produced on a simplex machine; finally, from each roving, two different count yarns were prepared as shown in Figure 1 and Table 2. Using LMW LRJ 60A ring frame machine with $12000 \mathrm{rpm}$ and $15000 \mathrm{rpm}$ spindle speed, 20 s and 40 s count of yarn with twist multiplier of 3.5 were prepared. As a result, a total of four types of yarns were produced for this study.

\subsubsection{Methods of Tensile and Yarn Evenness} Characterization. All yarn tensile strength and extension at break were examined, and also, during the experiment, four different types of yarn were tested on Instron 3365 based on ASTM D2256M. All tests were taken under standard testing conditions (65\% relative humidity and $27^{\circ} \mathrm{C}$ temperatures). Each yarn was cut in a gauge length of $25 \mathrm{~cm}$ according to ASTM D3365 standards. The test was run until the yarn 
TABLE 1: Physical properties of fibers used: nanocomposite PET and recycled PET fibers.

\begin{tabular}{lccccc}
\hline Materials & Fineness (denier) & Length $(\mathrm{mm})$ & Tenacity $(\mathrm{cN} / \mathrm{tex})$ & Elongation $(\%)$ & $\mathrm{Ag}^{0}$ concentration $(\mathrm{ppm})$ \\
\hline Nanocomposite polyester & 1.4 & 34 & 44.1 & 20.60 & 400 \\
Recycled polyester & 1.4 & 32 & 50.33 & 15.5 & Nil \\
\hline
\end{tabular}

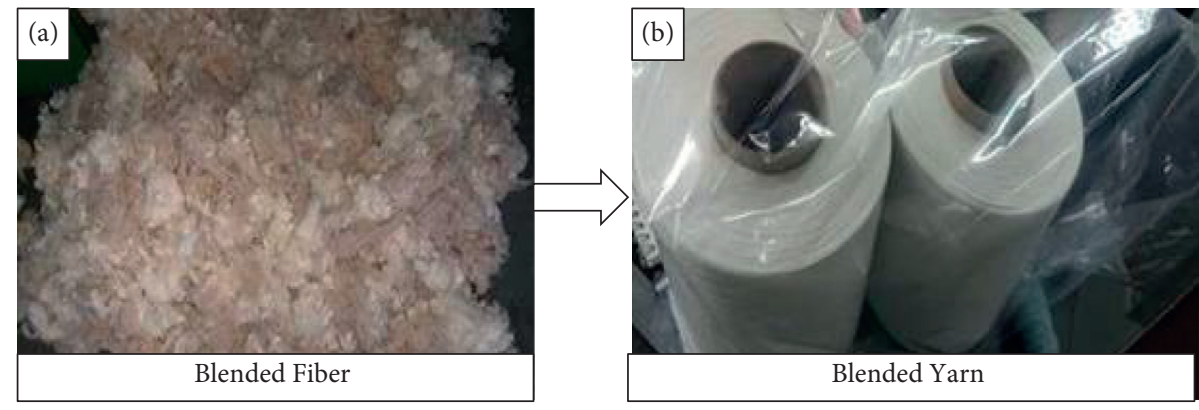

Figure 1: (a) Two blends of R-PET and SNC-PET (85:15 and 70:30). (b) Blended yarn.

TABLE 2: Number of samples with recycled polyester and silver nanocomposite polyester blend rate.

\begin{tabular}{lcccc}
\hline Recycled PET (\%) & Nanocomposite PET (\%) & Count (Ne) & No. of samples & Quantity (kg) \\
\hline 85 & 15 & 20 and 40 & 2 & 5 \\
70 & 30 & 20 and 40 & 2 & 5 \\
\hline
\end{tabular}

gradually pulled to failure (break) at a $300 \mathrm{~mm} / \mathrm{min}$ speed. There were ten samples examined from each yarn type. For yarn evenness, tests such as thin places, thick places, and NEP counts were performed on a Premiere unevenness testing machine based on ASTM D1425/D1425M with a $400 \mathrm{~m} / \mathrm{min}$ testing speed for 30 seconds. Five samples from each yarn type were tested.

2.2.3. Knitted Fabric Preparation. Four samples of single jersey plain knitted fabrics were prepared using Krinzler circular knitting machine with a machine diameter of 3.5 inches and 14 needles per inch. Table 3 shows the details of knitted fabric parameters. For fabric moisture vapor transmission rate testing PERME W3/0G0 machine was used. The testing temperature was $38^{\circ} \mathrm{C}$, relative humidity was $80 \%$, and two tests were done for each sample fabric.

2.2.4. Woven Fabric Preparation. Four types of plain-woven fabric samples were produced from the $20 \mathrm{~s}$ and $40 \mathrm{~s}$ yarns on CCI sample looms, and the details of samples are shown in Table 4. Hand-related properties of the woven fabric samples were carried out on Kawabata Evaluation System (KES), and Lab-think PERME W3/0G0 were used to test the moisture vapor transmission rate of woven fabric samples. The testing temperature and relative humidity were $38^{\circ} \mathrm{C}$ and $80 \%$ for moisture vapor transmission rate, and two tests were done for each sample fabric.

2.2.5. Scanning Electron Microscopy (SEM). Scanning electron microscopy (EVO 18) was used to characterize the surface morphology of nanocomposite fibers. Figure 2 shows SEM images of silver nanocomposite PET fiber with a 20,000 magnification scale. In this image, we can see many tiny particles on the polyester fiber surface, and these particles are relatively similar without the formation of any agglomerates.

2.2.6. Differential Scanning Calorimeter (DSC). DSC is a tool that operates thermodynamically for direct assessment of the heat energy uptake, which occurs in a sample within a regulated increase or decrease of temperature. The calorimeter is particularly applied to monitor the changes of phase transitions. The thermal property of the fibers was analyzed by the Universal V4.5ATA DSC instrument. DSC analysis of the fibers was carried out by heating the sample from atmospheric temperature to $300^{\circ} \mathrm{C}$ at a rate of $10^{\circ} \mathrm{C} / \mathrm{s}$. The fibers' melting temperature, melting enthalpy, and crystallinity percentage were calculated and are summarized in Table 5.

The crystallinity of the fibers can be obtained from expirations given as

$$
x_{c}=\frac{\Delta H_{m}}{\Delta H_{m}^{0}} \times 100 \%
$$

where $x_{c}$ is the percent crystallite, $\Delta H_{m}^{0}$ is the melting enthalpy of $100 \%$ crystallite PET $(105.97 \mathrm{~J} / \mathrm{g})$, and $\Delta H_{m}$ is the melting enthalpy of the sample fibers [17]. As shown in Figure 3 and Table 5, the thermal properties and crystallite percentage are almost the same.

2.2.7. Testing of Antimicrobial Activity. The antibacterial properties of the fabric were evaluated by using AATCC method 100A against E. coli (Gram-negative) and S. aureus (Gram-positive) bacteria. Two samples from each fabric 
Table 3: Details of knitted fabric parameters.

\begin{tabular}{lcccc}
\hline Yarn count $(\mathrm{Ne})$ & Blend ratio (R-PET: SNC-PET) & Wales $(\mathrm{cm})$ & Courses $(\mathrm{cm})$ & Fabric mass $(\mathrm{GSM})$ \\
\hline \multirow{2}{*}{20} & $85: 15$ & 19 & 24 & 224 \\
& $70: 30$ & 19 & 24 & 224 \\
\hline \multirow{2}{*}{40} & $85: 15$ & 22 & 27 & 155 \\
& $70: 30$ & 22 & 27 & 155 \\
\hline
\end{tabular}

TABLE 4: Details of woven fabric parameters.

\begin{tabular}{lcccc}
\hline Yarn count $(\mathrm{Ne})$ & Blend ratio (R-PET:SNC-PET) & PPI & EPI & Fabric mass $(\mathrm{GSM})$ \\
\hline \multirow{2}{*}{20} & $85: 15$ & 46 & 46 & 125 \\
& $70: 30$ & 46 & 46 & 125 \\
\multirow{2}{*}{40} & $85: 15$ & 92 & 92 & 125 \\
& $70: 30$ & 92 & 92 & 125 \\
\hline
\end{tabular}

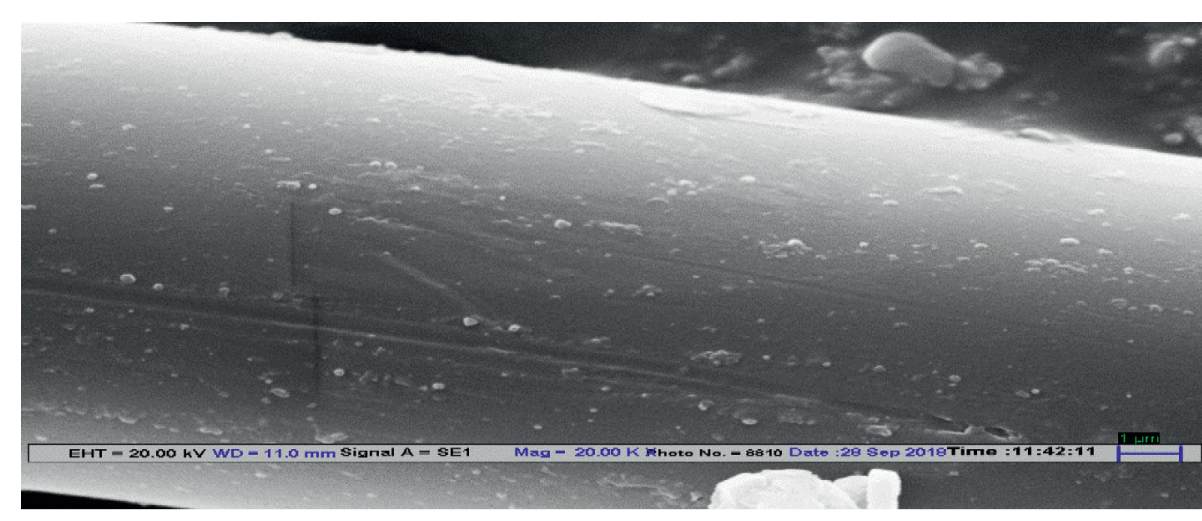

Figure 2: SEM images of silver nanocomposite PET.

TABLE 5: Thermal properties of fibers calculated from DSC curves.

\begin{tabular}{lccc}
\hline Fiber type & Melting temperature $\left({ }^{\circ} \mathrm{C}\right)$ & Melting enthalpy $(\mathrm{J} / \mathrm{g})$ & Crystallite percentage \\
\hline R-PET & 237.00 & 45.61 & 43.2 \\
SNPC-PET & 242.07 & 47.64 & 45 \\
\hline
\end{tabular}

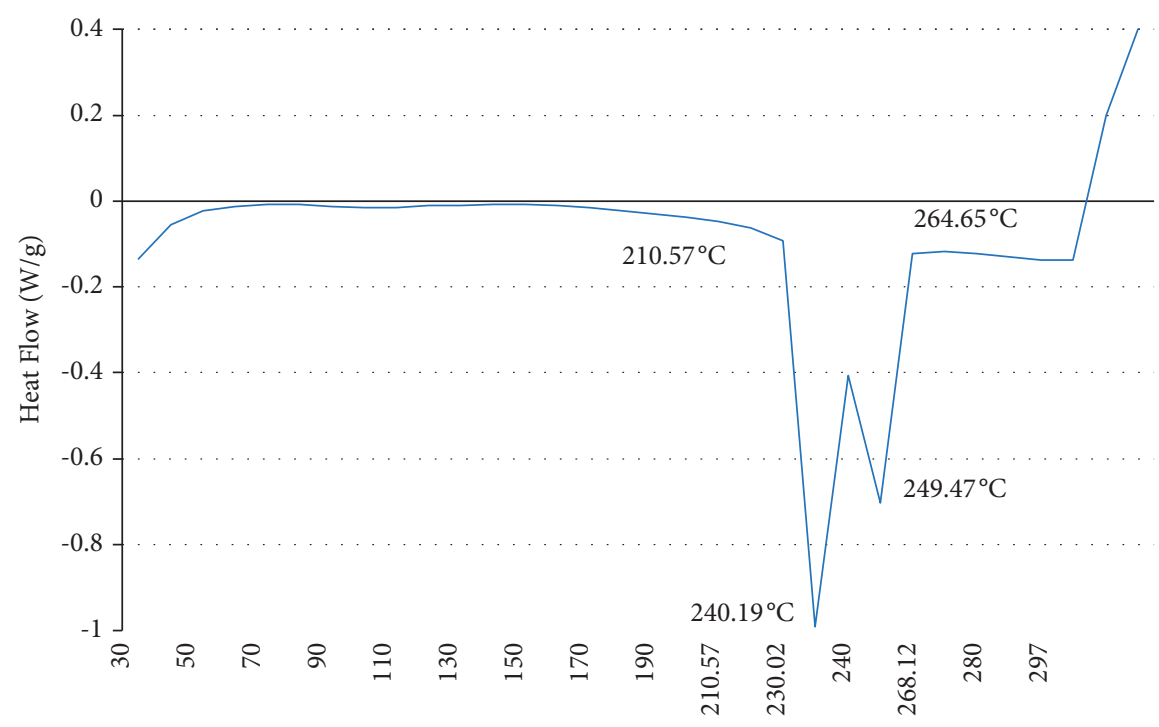

Temprature ${ }^{\circ} \mathrm{C}$

(a)

Figure 3: Continued. 


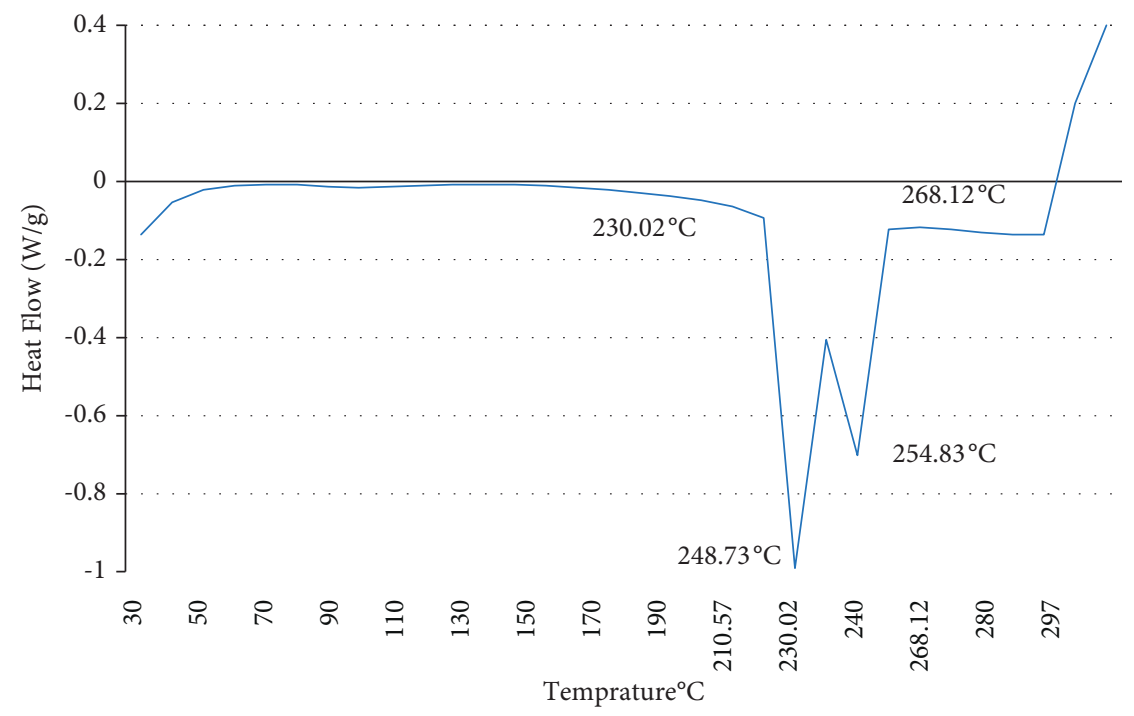

(b)

FIgURE 3: The DSC heating scan of (a) recycled PET and (b) nanocomposite PET.

were prepared for Gram-negative and Gram-positive bacterial testing with a sample size of $2 \mathrm{~cm} \times 1 \mathrm{~cm}$. For solidifying, bacterial growth and bacterial dilution solutions are prepared from agar (solidifying agent) and Luria broth (bacterial growth).

All the samples, solutions, and equipments (micropipettes, Petri plates, spreaders, and test tubes) ware pasteurized for 20 minutes. A bacterial solution of $0.1 \mathrm{ml}$ is added to each test tube with 9.9 milliliters of distilled water, and then the samples are stacked inside the test tubes. The test tubes were tightly covered with cotton and placed in a shaking incubator at $37^{\circ} \mathrm{C}$ for 24 hours to prevent evaporation, as shown in Figure 4.

The bacterial solution from the test tube was diluted six times (six dilutions), and a Petri plate for each sample also were prepared. 20 milliliters of agar and Luria broth solution is put to each Petri plate. After six dilutions of bacterial solution, 0.1 milliliters of bacterial solution from the $6^{\text {th }}$ test tube was added to each Petri plate and spread using spreaders, as shown in Figure 5.

The Petri plates were placed in the incubator at $37^{\circ} \mathrm{C}$ for 24 hours. After 24-hour incubation time, the bacterial colonies were counted on the Petri plates, and the percentage reduction of bacteria was calculated using the following expression:

$$
R(\%)=\left(\frac{\left[\left(C_{0}-C\right)\right]}{C_{0}}\right) \times 100,
$$

where $C_{0}$ represents the number of bacterial colonies on the untreated fabric and $C$ represents the number of bacterial colonies on the fabric loaded with silver NPs.

2.2.8. Agar Diffusion Test. The agar diffusion tests include AATCC 147-2004 (American Association of Textile Chemists and Colorists), JIS L 1902-2002 (Japanese
Industrial Standards), and SN 1959-201992 (Swiss Norm). They are only qualitative but simple to perform and most suitable when many samples are to be screened for the presence of antimicrobial activity. In these tests, bacterial cells were inoculated on nutrient agar plates over which textile samples were also laid for intimate contact. The plates were incubated at $37^{\circ} \mathrm{C}$ for $18-24$ hours and examined for the growth of bacteria directly underneath the fabrics and immediately around the edges of the fabrics (zone of inhibition). No bacterial growth directly underneath the fabric sample indicates the presence of antimicrobial activity.

The zone of inhibition should not be expected if the antimicrobial agent is firmly attached to the textile (e.g., covalently), which prevents its diffusion into the agar. If the antimicrobial agent can diffuse into the agar, a zone of inhibition becomes apparent. Its size indicates the potency of the antimicrobial activity or the release rate of the active agent [18].

2.2.9. Suspension Test. This type of test is illustrated by AATCC 100-2004, JIS L 1902-2002, and SN 195924-1992. These methods were provided quantitative values on the antimicrobial finishing but were more time-consuming than agar diffusion tests. Typically, a small volume (e.g., $1 \mathrm{ml}$ ) of bacterial inoculum in a growth media is fully absorbed into fabric samples of appropriate size without leaving any free liquid. This process ensures intimate contact between the fabric and the bacteria. After incubating, inoculated fabrics were kept in sealed jars at $37^{\circ} \mathrm{C}$ or $27^{\circ} \mathrm{C}$ for up to $24 \mathrm{~h}$, and the bacteria in the fabric were eluted. The total number is determined by serial dilution and plating on nutrient agar plates.

Antimicrobial activities expressed as a percentage of reduction were also calculated by comparing the size of the initial population with that following the incubation. Appropriate controls, e.g., samples that have gone through the 


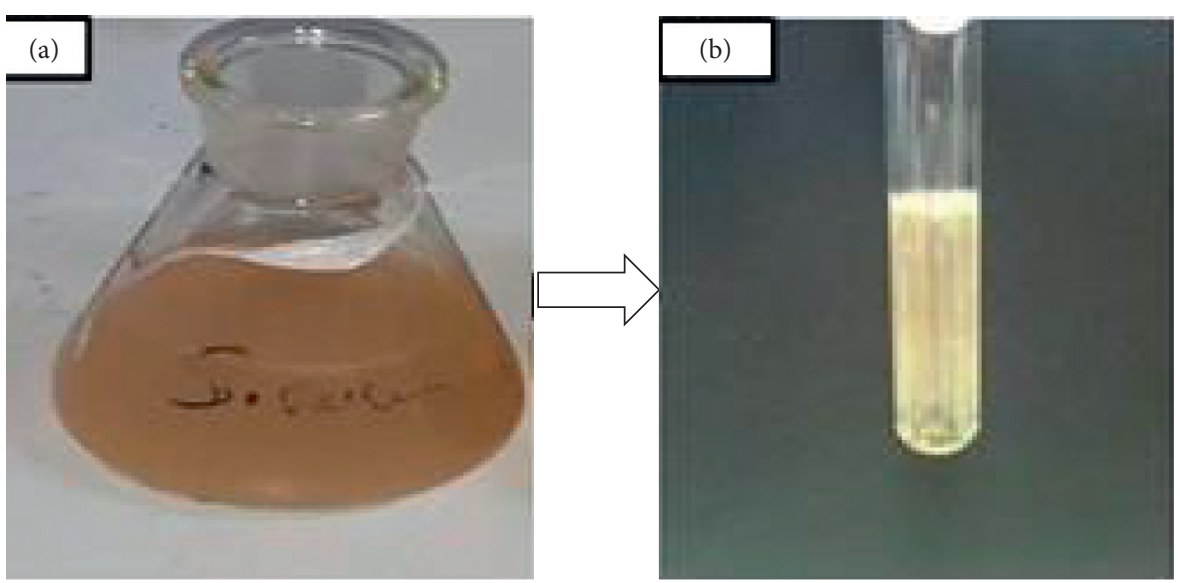

Figure 4: (a) Gram-negative and Gram-positive bacteria. (b) Putting the sample in a solution of $0.1 \mathrm{ml}$ bacteria and $9.9 \mathrm{ml}$ distilled water.

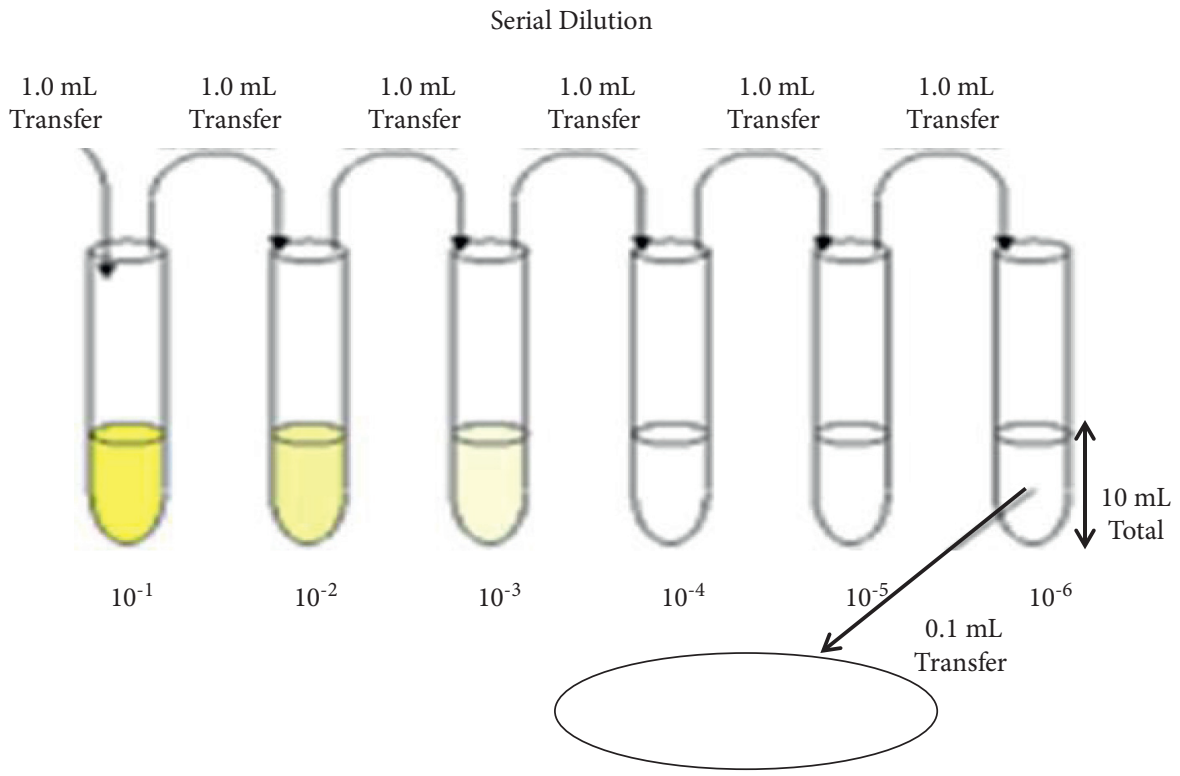

Figure 5: Bacterial solution dilution processes.

same processing except the antimicrobial finishing, should be included in each experiment to ascertain that observed decrease in bacterial number due to the antimicrobial finishing.

It should be noted that suspension tests were often performed under artificial conditions that promote bacterial growth (e.g., rich nutrients in the inoculum and saturating moisture in the testing fabrics). The moisture in the tests is also essential for the action of the biocide. To date, very few studies have examined the antimicrobial effects under normal wearing conditions. To more closely mimic the reallife situation, the JIS L 1902-2002 method recommends using bacterial cells suspended in heavily diluted nutrient media to limit nutrient levels. The ISO (International Organization for Standardization) has developed a test method (ISO 20743) in which bacteria were printed onto the surface of textiles without being in an aqueous suspension. The printed samples were incubated under humid conditions at $20^{\circ} \mathrm{C}$ for a specified time (18-24 hours), following which the surviving cells were counted [16].

\section{Results and Discussion}

\subsection{Characterization of Yarn Properties}

3.1.1. Tensile Characterization. The tensile testing properties of yarns were performed for all samples to know each sample's strength and elongation properties, to decide further parameters for any other kind of tests. The tensile test results for each sample are shown in Figures 6 and 7 as tabulated in Table 6. From the obtained result, it is evident that the tensile strength of ring-spun yarn is mainly affected by the strength of constituent fibers in the yarn, and that is why the tensile strength of the yarn sample becomes lower when the percentage proportion of silver nanocomposite PET fiber is higher in the blend ratio, which is due to the lower strength of silver nanocomposite PET fibers compared to recycled PET fibers.

3.1.2. Yarn Evenness Characterization. From the obtained result, the numbers of thick places and NEP were found to be high for fine yarn samples. As shown in Table 6 and Figures 8 


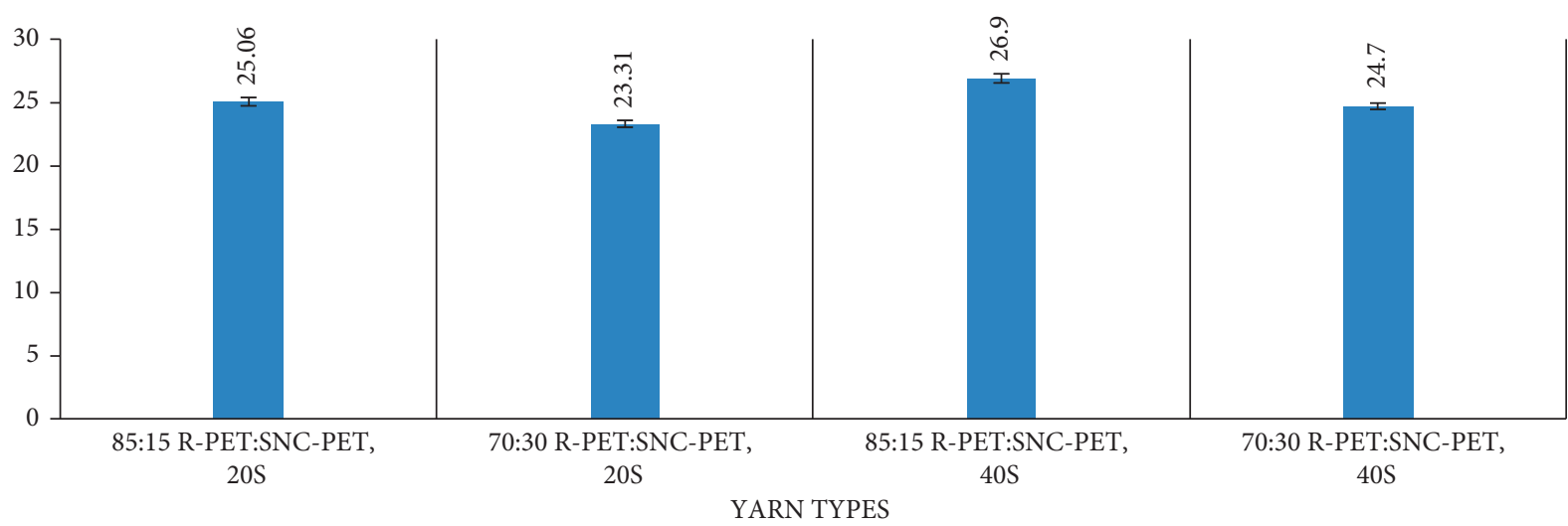

Tenacity (gf/tex)

Figure 6: Tenacity of yarn samples.

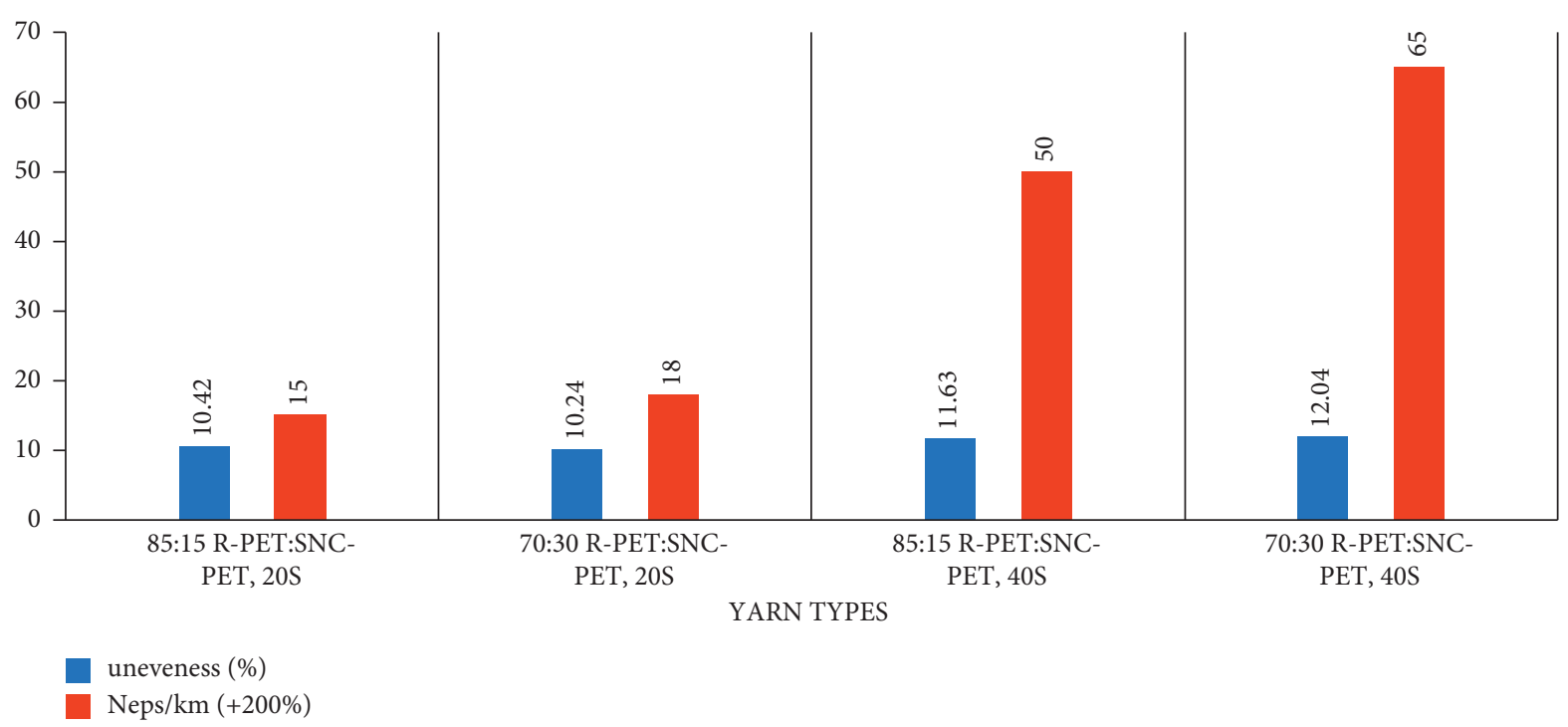

FIgURE 7: NEP counts $(+200 \%)$ and unevenness of yarn samples.

TABle 6: Tensile and evenness properties of yarns.

\begin{tabular}{|c|c|c|c|c|c|c|c|c|}
\hline \multirow{2}{*}{$\begin{array}{l}\text { Yarn details } \\
\text { (R-PET : SNC- } \\
\text { PET) }\end{array}$} & \multicolumn{2}{|c|}{ Tenacity } & \multicolumn{2}{|c|}{ Elongation } & \multirow[b]{2}{*}{ Unevenness (\%) } & \multirow{2}{*}{$\begin{array}{l}\text { Thin places } \\
(\mathrm{km}) \\
(-50 \%)\end{array}$} & \multirow{2}{*}{$\begin{array}{c}\text { Thick places } \\
(\mathrm{km}) \\
(+50) \mathrm{gf} / \mathrm{tex}\end{array}$} & \multirow{2}{*}{$\begin{array}{c}\text { Nap's }(\mathrm{km}) \\
(+200 \%) \\
\text { standard deviation }\end{array}$} \\
\hline & $\begin{array}{l}\text { gf/ } \\
\text { tex }\end{array}$ & $\begin{array}{l}\text { Standard } \\
\text { deviation }\end{array}$ & $\%$ & $\begin{array}{l}\text { Standard } \\
\text { deviation }\end{array}$ & & & & \\
\hline $85: 15(20 \mathrm{Ne})$ & 25.1 & 0.33 & 13.01 & 1.14 & 10.42 & 1 & 17 & 15 \\
\hline $70: 30(20 \mathrm{Ne})$ & 23.31 & 0.27 & 15.48 & 2.05 & 10.24 & 6 & 20 & 18 \\
\hline $85: 15(40 \mathrm{Ne})$ & 26.9 & 0.36 & 12.3 & 1.16 & 11.63 & 8 & 50 & 50 \\
\hline $70: 30(40 \mathrm{Ne})$ & 24.7 & 0.25 & 13.67 & 1.51 & 12.04 & 24 & 73 & 65 \\
\hline
\end{tabular}

and 9, the thin place, thick place, and NEP percentages increase as the silver nanocomposite PET ratio increases in the yarn. This may be due to the different surface properties of two polyester fibers.

\subsection{Characterization of Fabric Properties}

3.2.1. Kawabata Evaluation System (KES). Many texture/ hand-related properties of the produced fabrics were measured using KES testing instruments such as tensile and shear tester (KES-F1), bending tester (KES-F2), compression tester (KES-F3), and surface and friction tester (KES-F4). The tensile, shear, bending, and surface property measurements were carried out in warp and weft directions. The average value of the measurement in two directions is presented in Table 7.

Table 7 explains that the resilience is higher in fabrics made from a lower blend ratio of SNP-PET fiber in both counts of yarn. There is no significant difference in the tensile linearity of fabrics that were made from both blend types. The tensile property is higher in the case of fabrics with a lower SNC-PET fiber blend ratio with a count of $20 \mathrm{~s}$ 


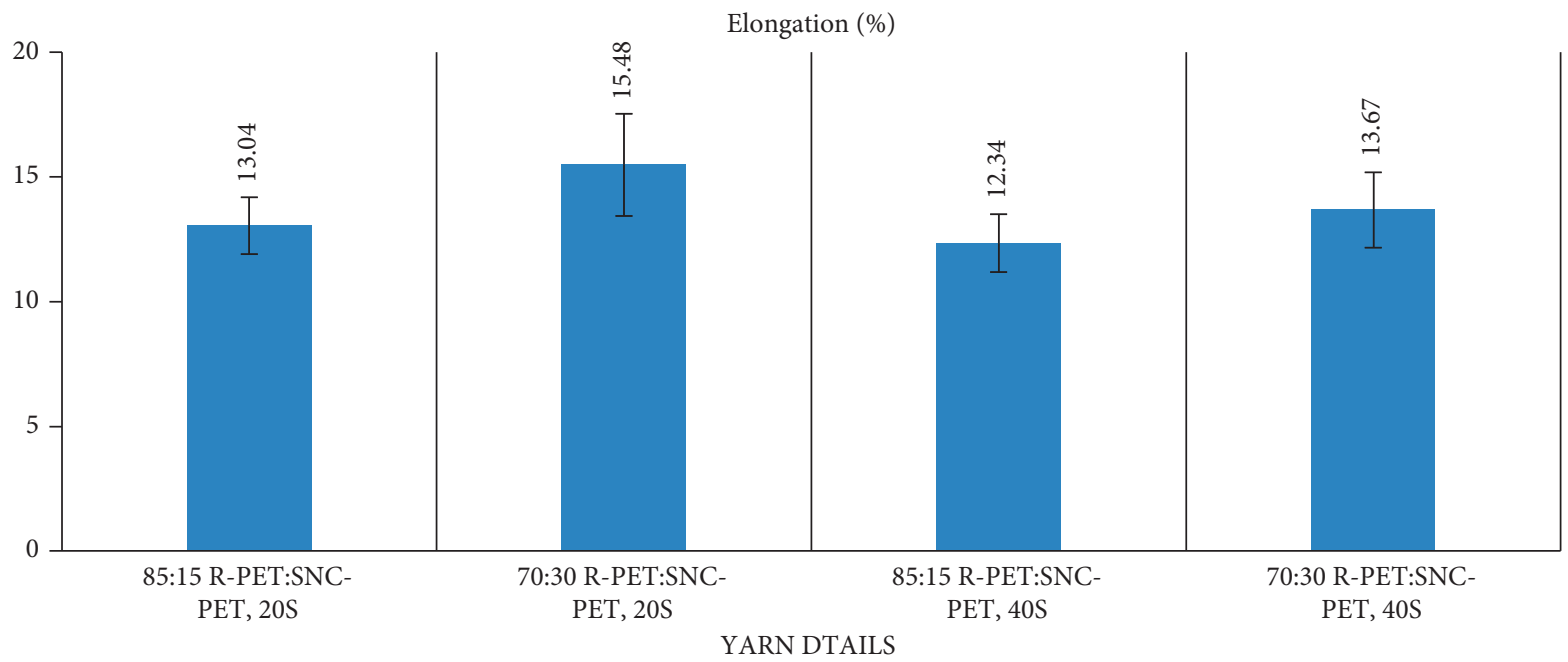

Elongation (\%)

Figure 8: Elongation of the blended yarn sample.

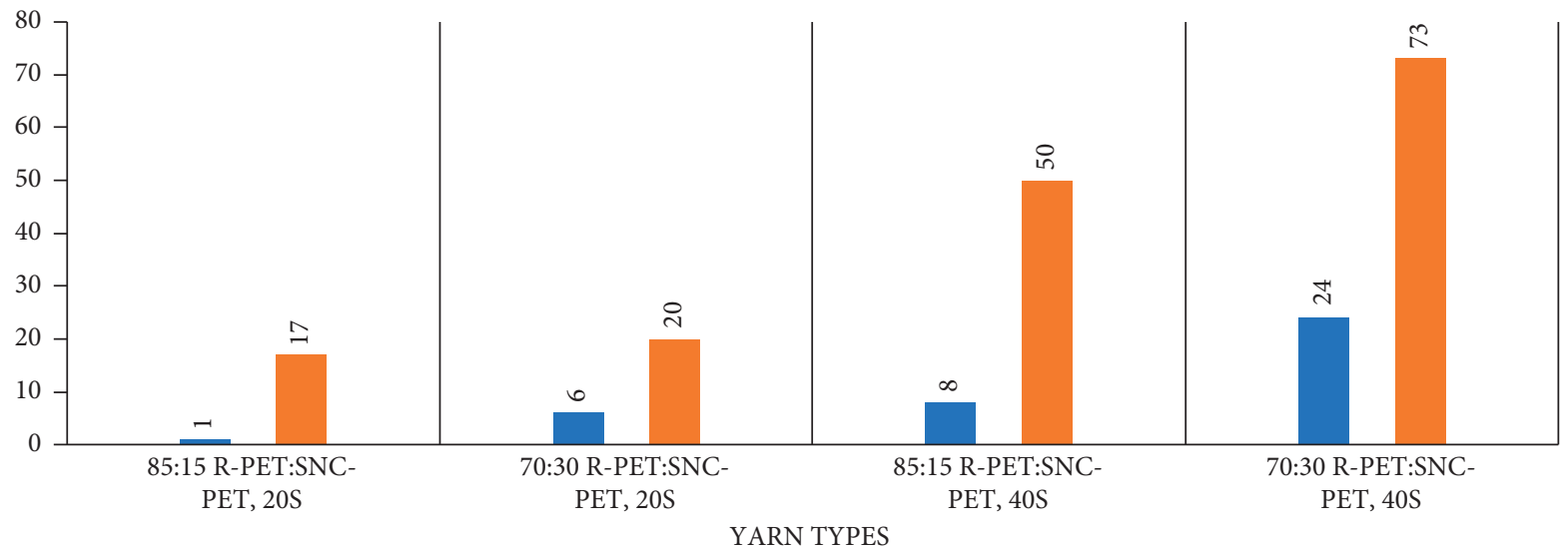

Thin places $/ \mathrm{km}(-50 \%)$

Thick places $/ \mathrm{km}(+50 \%)$

FIgURE 9: Thick and thin places of the blended yarn sample.

TABLe 7: Statistical results of KES-F indices of four fabric samples.

\begin{tabular}{|c|c|c|c|c|c|}
\hline KES & Indices & $\begin{array}{c}\text { R-PET : SNP-PET } \\
\quad(85: 15), 20 \mathrm{~s}\end{array}$ & $\begin{array}{l}\text { R-PET : SNP-PET } \\
\quad(70: 30), 20 \mathrm{~s}\end{array}$ & $\begin{array}{c}\text { R-PET : SNP-PET } \\
(85: 15), 40 \mathrm{~s}\end{array}$ & $\begin{array}{c}\text { R-PET : SNP- PET } \\
\quad(70: 30), 40 \mathrm{~s}\end{array}$ \\
\hline \multirow{3}{*}{ FB1 tensile properties } & LT $(-)$ & 0.60 & 0.64 & 0.79 & 0.82 \\
\hline & WT $\left(\mathrm{gf} . \mathrm{cm} / \mathrm{cm}^{2}\right)$ & 15.5 & 13.8 & 9.1 & 10.6 \\
\hline & RT $(\%)$ & 58.7 & 56.5 & 57.99 & 55.77 \\
\hline \multirow{2}{*}{ FB2 bending } & $\mathrm{B}\left(\mathrm{gf} . \mathrm{cm}^{2} / \mathrm{cm}\right)$ & 0.13 & 0.2 & 0.26 & 0.29 \\
\hline & $2 \mathrm{HB}(\mathrm{gf} . \mathrm{cm} / \mathrm{cm})$ & 0.06 & 0.09 & 0.18 & 0.21 \\
\hline \multirow{3}{*}{ FB2 shear properties } & $\mathrm{G}$ & 0.28 & 0.34 & 3.52 & 4.13 \\
\hline & $2 \mathrm{HG}$ & 0.385 & 0.435 & 1.60 & 1.78 \\
\hline & 2HG5 & 1.05 & 1.32 & 9.02 & 9.09 \\
\hline \multirow{4}{*}{$\begin{array}{l}\text { FB3 compressional } \\
\text { behavior }\end{array}$} & LC & 0.35 & 0.33 & 0.38 & 0.44 \\
\hline & $\mathrm{WC}\left(\mathrm{gf} / \mathrm{cm}^{2}\right)$ & 0.1 & 0.11 & 0.08 & 0.07 \\
\hline & $\mathrm{RC}(\%)$ & 51.3 & 53.1 & 53.3 & 53.8 \\
\hline & $\mathrm{T}(\mathrm{mm})$ & 0.45 & 0.51 & 0.4 & 0.37 \\
\hline \multirow{3}{*}{ FB4 surface roughness } & MIU-1 & 2.09 & 2.21 & 1.79 & 1.98 \\
\hline & MMD-1 & 1.8 & 2.03 & 1.39 & 1.66 \\
\hline & SMD-1 & 6.47 & 7.25 & 3.38 & 4.15 \\
\hline Areal density & $\mathrm{mg} / \mathrm{sq} . \mathrm{cm}$ & 13.53 & 13.62 & 14.42 & 14.46 \\
\hline
\end{tabular}


TABLE 8: The moisture vapor transmission rate (MVTR) of knitted fabric.

\begin{tabular}{lcccc}
\hline Count $(\mathrm{s})$ & Blend ratio (R-PET :SNPC-PET) & Thickness $(\mathrm{mm})$ & GSM & WVTR $\left(\mathrm{g} / \mathrm{m}^{2} \cdot\right.$ day) \\
\hline \multirow{2}{*}{20} & $85: 15$ & 1.06 & 224 & 6180 \\
& $70: 30$ & 1.09 & 224 & 5073 \\
\hline \multirow{2}{*}{40} & $85: 15$ & 0.65 & 155 & 7101 \\
& $70: 30$ & 0.75 & 155 & 7299 \\
\hline
\end{tabular}

TABLE 9: The moisture vapor transmission rate (MVTR) of woven fabric.

\begin{tabular}{lcccccc}
\hline Count $(\mathrm{s})$ & Blend ratio & Thickness $(\mathrm{mm})$ & EPI & PPI & GSM & WVTR $\left(\mathrm{g} / \mathrm{m}^{2} \cdot\right.$ day) \\
\hline \multirow{2}{*}{20} & $85: 15$ & 0.320 & 46 & 46 & 135 & 6132 \\
& $70: 30$ & 0.332 & 46 & 46 & 135 & 6025 \\
\hline \multirow{2}{*}{40} & $85: 15$ & 0.240 & 92 & 92 & 141 & 5789 \\
& $70: 30$ & 0.258 & 92 & 92 & 141 & 5582 \\
\hline
\end{tabular}

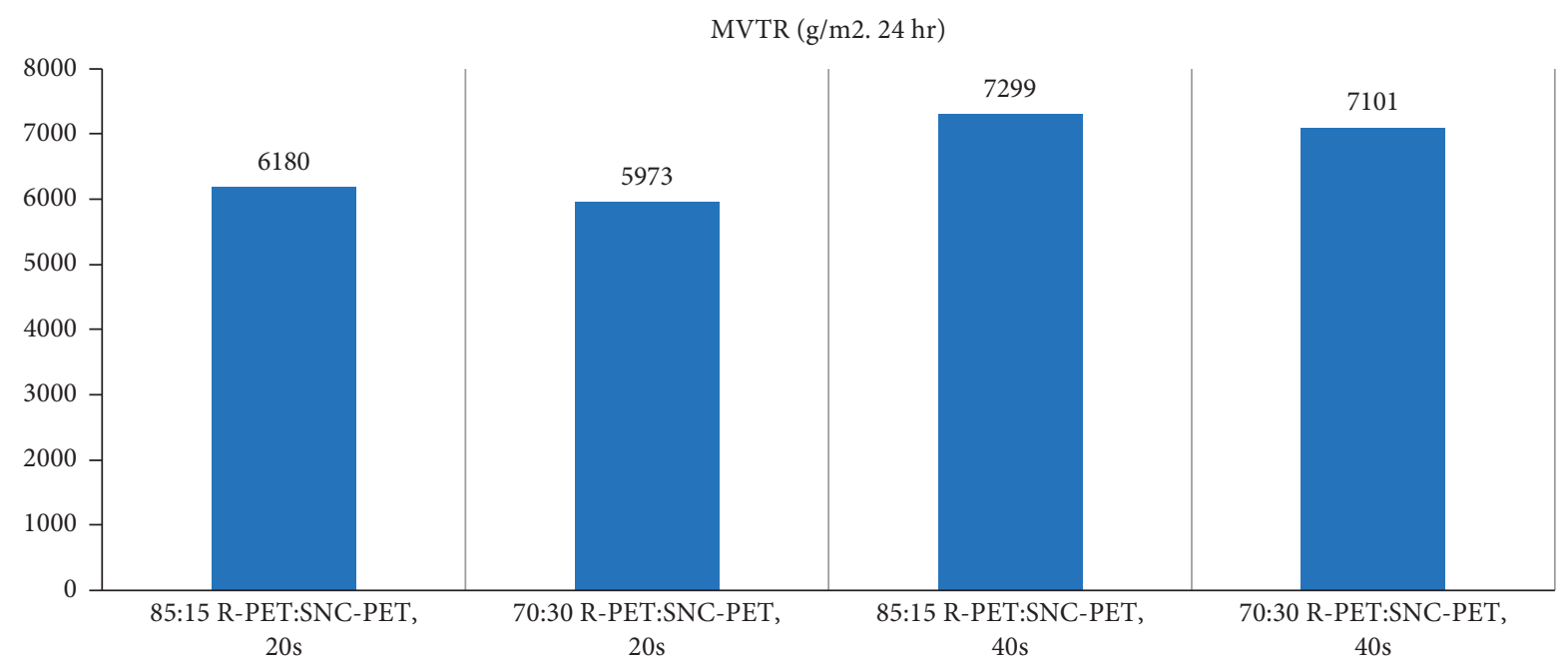

MVTR (g/m2. 24hr)

Figure 10: MVTR (g/m2. $24 \mathrm{hr}$ ) of the knitted fabric sample.

yarn and almost the same for both blends in case of the fabric made from $40 \mathrm{~s}$ yarn. Additionally, from the results, the fabric's bending rigidity and shearing rigidity with a higher silver SNC-PET fiber ratio are higher. But shearing hysteresis and bending recovery do not show any significant difference according to the result. Compressional linearity and compressive energy are almost the same for fabrics made from both kinds of blends. The coefficient of friction and surface roughness are higher in the case of fabric samples with higher SNC-PET fiber for both types of yarn counts. Generally, we found that fabric samples with a lower SNC-PET fiber ratio in the blended yarn are softer and smoother and have good drapability for both types of yarn count.

3.2.2. Moisture Vapor Transmission Rate (MVTR). The moisture vapor transmission rate of both knitted and woven fabric samples was tested by using PERME W3/0G0 under a certain test temperature and relative humidity, and a vapor pressure difference was generated between two sides of the test specimen. The water vapor is carried away by a flowing stream of dry gas on one side, and the weight loss on another side was intermittently measured to obtain the water vapor transmission rate. Three specimens were tested for each fabric sample at a temperature of $38^{\circ} \mathrm{C}$ and a relative humidity of $80 \%$, and the average moisture vapor transmission rate (MVTR) of sample fabrics is tabulated in Tables 8 and 9 and given in Figures 10 and 11 .

Thickness and openness (EPI and PPI) of the fabric affect the fabrics' MVTR, which is why the MVTR of knitted fabric with lower thickness is higher. In the case of woven fabric samples, the MVTR of fabric with lower EPI and PPI (more open fabric) is higher.

3.2.3. Antibacterial Results. As it is mentioned in the testing procedure above, four samples from two blend ratios of recycled PET and silver nanocomposite PET for each fabric sample type were tested against E. coli (Gram-negative) and S. aureus (Gram-positive) bacteria. The bacterial growth and the inhabitation are depicted in Figures 12(a)-12(c). 


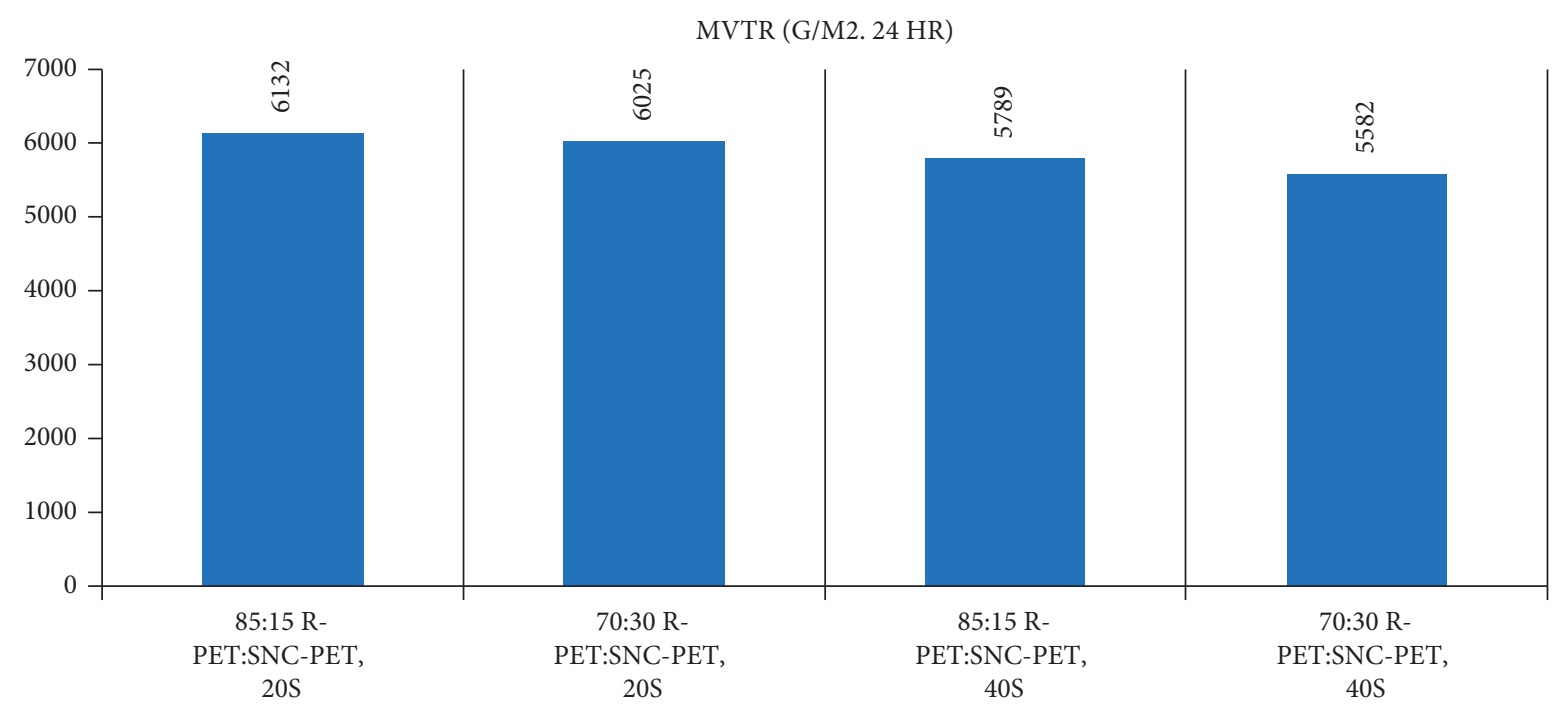

FABRIC SAMPLES

MVTR (G/M2. 24HR)

Figure 11: MVTR (g/m2. $24 \mathrm{hr})$ of the woven fabric samples.

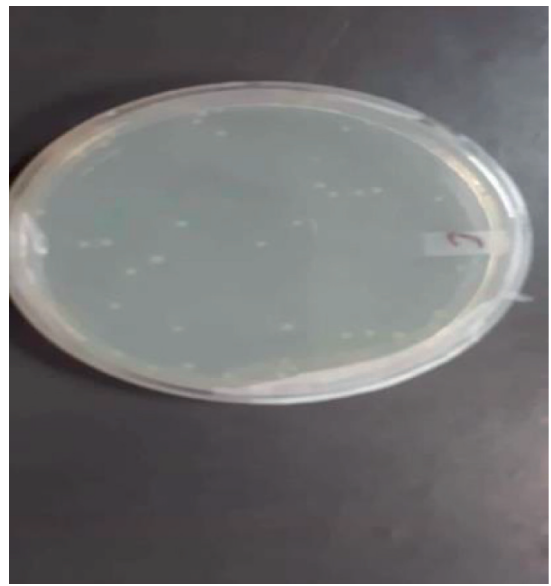

(a)

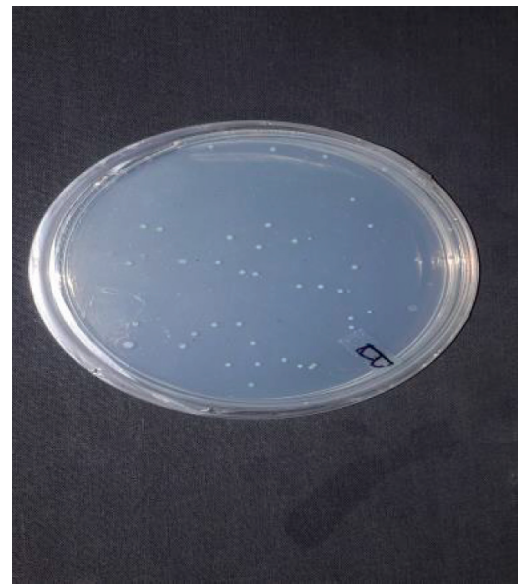

(b)

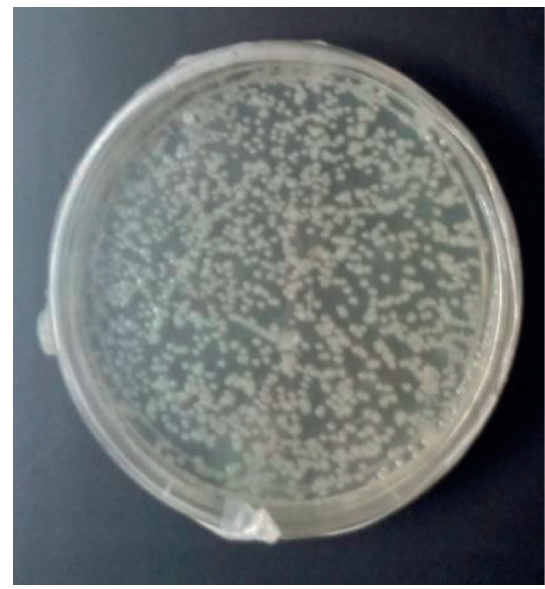

(c)

FIGURE 12: Bacterial growth and inhabitation.

TABLE 10: Antibacterial activity results for S. aureus (Gram-positive).

\begin{tabular}{|c|c|c|c|c|}
\hline Fabric type & Yarn count $(\mathrm{Ne})$ & Blend ratio (R-PET:SNC-PET) & Number of bacterial colonies & Bacterial reduction (\%) \\
\hline \multirow{4}{*}{ Knitted fabric } & \multirow{2}{*}{20} & $85: 15$ & 32 & 95.6 \\
\hline & & $70: 30$ & 5 & 98.9 \\
\hline & \multirow{2}{*}{40} & $85: 15$ & 41 & 91.2 \\
\hline & & $70: 30$ & 18 & 96.1 \\
\hline \multirow{4}{*}{ Woven fabric } & \multirow{2}{*}{20} & $85: 15$ & 64 & 91.5 \\
\hline & & $70: 30$ & 31 & 95.5 \\
\hline & \multirow{2}{*}{40} & $85: 15$ & 50 & 93 \\
\hline & & $70: 30$ & 26 & 97 \\
\hline
\end{tabular}

Figures 12(a) and 12(b) show bacterial growth inhabitation after 24-hour growth time of fabric made from 15:85 and 30: 70 blend ratio of SNC-PET and recycled PET fibers, respectively, and Figure 12(c) shows bacterial growth in fabric made from $100 \%$ recycled PET after 24 -hour growth time. The percentage reduction of bacteria is calculated using the formula mentioned above in the procedure, and the antibacterial activity result of the fabric is discussed in Tables 10 and 11. 
TABLE 11: Antibacterial activity results for E. coli (Gram-negative).

\begin{tabular}{|c|c|c|c|c|}
\hline Fabric type & Yarn count $(\mathrm{Ne})$ & Blend ratio (R-PET:SNC-PET) & Number of bacterial colonies & Bacterial reduction $(\%)$ \\
\hline \multirow{4}{*}{ Knitted fabric } & \multirow{2}{*}{20} & $85: 15$ & 35 & 96.3 \\
\hline & & $70: 30$ & 4 & 99 \\
\hline & \multirow{2}{*}{40} & $85: 15$ & 45 & 95.2 \\
\hline & & $70: 30$ & 15 & 98 \\
\hline \multirow{4}{*}{ Woven fabric } & \multirow{2}{*}{20} & $85: 15$ & 15 & 96.5 \\
\hline & & $70: 30$ & 4 & 98.2 \\
\hline & \multirow{2}{*}{40} & $85: 15$ & 11 & 97.5 \\
\hline & & $70: 30$ & 5 & 99 \\
\hline
\end{tabular}

As evident from Table 10 results, the antibacterial activity of both knitted and woven fabric, the number of bacterial colonies become reduced when the percentage of nanocomposite PET fiber increased in the yarn blend of both fabric types. In the case of fabrics made from coarser yarn, the interaction between bacteria and nanocomposite fiber increases; that is why the antibacterial activity of fabrics made from coarser yarn is better.

The antibacterial activity of fabric increases with the increment of the percentage of nanocomposite fibers in the yarn blend. Woven fabrics with higher cover factors (higher EPI and PPI) have more yarn surface per unit area. In both types of blend ratios and for all fabric types, the reduction of bacterial colonies was reasonably acceptable. All manufactured fabric samples were found to be effective against both E. coli and $S$. aureus bacterial types.

\section{Conclusions}

In this study, we analyze the produced sustainable, functional woven and knitted fabrics from recycled and nanocomposite polyester fibers. The results show that the yarn tensile strength decreases, and the unevenness of the yarn increases as the proportion of nanocomposite fiber increases in the blend. The woven fabrics produced from both types of yarn count show more surface roughness, higher bending rigidity, and rough texture when the percentage of SNC-PET fiber ratio becomes more in the blend.

According to the results, we examined that the percentage of nanocomposite fiber is more in the blend, and the antimicrobial activity in the developed fabric becomes higher. On the other hand, when the count of yarn increases (decrease in yarn diameter), it decreases the antimicrobial activity of the developed fabrics. The increase in cover factor (EPI and PPI) leads to a gradual increase in the antimicrobial activity of the woven fabric. All developed fabrics show reasonably acceptable antimicrobial activity in both blends. And also, the developed fabric was found to be effective against both E. coli and $S$. aureus bacterial types [9].

\section{Data Availability}

The data supporting the findings of this study are all included within the article.

\section{Conflicts of Interest}

The authors declare that there are no conflicts of interest.

\section{References}

[1] H. Aslani, P. Pashmtab, A. Shaghaghi, A. Mohammadpoorasl, H. Taghipour, and M. Zarei, "Tendencies towards bottled drinking water consumption: challenges ahead of polyethylene terephthalate (PET) waste management," Health Promotion Perspectives, vol. 11, no. 1, pp. 60-68, 2021.

[2] L. Biermann, E. Brepohl, C. Eichert, M. Paschetag, M. Watts, and S. Scholl, "Development of a continuous PET depolymerization process as a basis for a back-to-monomer recycling method," Green Processing and Synthesis, vol. 10, no. 1, pp. 361-373, 2021.

[3] N. Thachnatharen, S. Shahabuddin, and N. Sridewi, "The waste management of Polyethylene Terephthalate (PET) plastic waste: a review," IOP Conference Series: Materials Science and Engineering, vol. 1127, no. 1, Paper presented at the, Article ID 012002, 2021.

[4] M. M. Ben Zair, F. M. Jakarni, R. Muniandy, and S. Hassim, "A brief review: application of recycled polyethylene terephthalate in asphalt pavement reinforcement," Sustainability, vol. 13, no. 3, p. 1303, 2021.

[5] L. Bartolome, M. Imran, B. Gyoo Cho, W. A. Al-Masry, and Do Hyun Kim, "Recent developments in chemical recycling of PET," Material Recycling - Trends and Perspectives, Books on Demand, Norderstedt, Germany, 2012.

[6] D. Paszun and T. Spychaj, "Chemical recycling of poly (ethylene terephthalate)," Industrial \& Engineering Chemistry Research, vol. 36, no. 4, pp. 1373-1383, 1997.

[7] L. Shen, E. Worrell, and M. K. Patel, "Open-loop recycling: a LCA case study of PET bottle-to-fibre recycling," Resources, Conservation and Recycling, vol. 55, no. 1, pp. 34-52, 2010.

[8] S. He, M. Wei, M. Liu, and W. Xue, "Characterization of virgin and recycled poly (ethylene terephthalate) (PET) fibers," Textile Institute, vol. 106, no. 8, pp. 800-806, 2004.

[9] T. Abdurrahman and Ö. Nilgün, "Effect of recycled PET fibers on the performance properties of knitted fabrics," Engineered Fibers and Fabrics, vol. 10, pp. 47-60, 2013.

[10] J. Chu, Y. Cai, C. Li, X. Wang, Q. Liu, and M. He, "Dynamic flows of polyethylene terephthalate (PET) plastic in China," Waste Management, vol. 124, pp. 273-282, 2021.

[11] M. Colnik, Z. Knez, and M. Skerget, "Sub-and supercritical water for chemical recycling of polyethylene terephthalate waste," Chemical Engineering Science, vol. 233, Article ID 116389, 2021.

[12] S. Cornago, D. Rovelli, C. Brondi et al., "Stochastic consequential Life Cycle Assessment of technology substitution in the case of a novel PET chemical recycling technology," Journal of Cleaner Production, vol. 311, Article ID 127406, 2021.

[13] N. A. Wilson García, J. L. Almaral Sánchez, R. Á. Vargas Ortiz et al., "Physical and mechanical properties of unsaturated 
polyester resin matrix from recycled PET (based PG ) with corn straw fiber," Journal of Applied Polymer Science, vol. 138, no. 44, Article ID 51305, 2021.

[14] A. Kakoria, S. S. Chandel, and S. Sinha-Ray, "Novel supersonically solution blown of nanofibers from waste PET bottle for PM0.1-2 filtration: from waste to pollution mitigation," Polymer, vol. 234, Article ID 124260, 2021.

[15] M. Ubaidullah, A. M. Al-Enizi, T. Ahamad et al., "Fabrication of highly porous $\mathrm{N}$-doped mesoporous carbon using waste polyethylene terephthalate bottle-based MOF-5 for high performance supercapacitor," Journal of Energy Storage, vol. 33, Article ID 102125, 2021.

[16] M. D. Teli and R. D. Kale, "Polyester nanocomposite fibers with antibacterial properties," Advances in Applied Science Research, vol. 2, no. 4, pp. 491-502, 2011.

[17] S. Wang, W. Hou, L. Wei et al., "Structure and properties of composite antibacterial PET fibers," Journal of Applied Polymer Science, vol. 112, pp. 1927-1932, 2009.

[18] K. Chan and A. Zinchenko, "Conversion of waste bottles' PET to a hydrogel adsorbent via PET aminolysis," Journal of Environmental Chemical Engineering, vol. 9, no. 5, Article ID 106129, 2021.

[19] O. Semyonov, S. Chaemchuen, A. Ivanov et al., "Smart recycling of PET to sorbents for insecticides through in situ MOF growth," Applied Materials Today, vol. 22, Article ID 100910, 2021.

[20] N. Dura'n, P. D. Marcato, G. De Souza, O. L. Alves, and E. Esposito, "Antibacterial effect of silver nanoparticles produced by fungal process on textile fabrics and their effluent treatment," Journal of Biomedical Nanotechnology, vol. 3, pp. 203-208, 2007.

[21] M. Rai, A. Yadav, and A. Gade, "Silver nanoparticles as a new generation of antimicrobials," Biotechnology Advances, vol. 27, no. 1, pp. 76-83, 2009.

[22] H. J. Lee, S. Y. Yeo, and S. H. Jeong, "Antibacterial effect of nanosized silver colloidal solution on textile fabrics," Journal of Materials Science, vol. 38, no. 10, pp. 2199-2204, 2003.

[23] S. W. Ali, S. Rajendran, and M. Joshi, "Synthesis and characterization of chitosan and silver loaded chitosan nanoparticles for bioactive polyester," Carbohydrate Polymers, vol. 83, no. 2, pp. 438-446, 2011.

[24] F. Ding, S. Zhang, X. Ren, and T.-S. Huang, "Development of PET Fabrics Containing N-halamine compounds with durable antibacterial property," Fibers and Polymers, pp. 1-10, 2021.

[25] Y. Lai, Y. Guo, L. Xu et al., "Plasma enhanced fluorine-free superhydrophobic polyester (PET) fabric with ultra-robust antibacterial and antibacterial adhesion properties," Coatings, vol. 11, no. 1, p. 15, 2021.

[26] A. Kędziora, R. Wieczorek, M. Speruda et al., "Comparison of antibacterial mode of action of silver ions and silver nanoformulations with different physico-chemical properties: experimental and computational studies," Frontiers in Microbiology, vol. 12, p. 1707, 2021.

[27] N. Lu, Z. Chen, W. Zhang et al., "Effect of silver ion implantation on antibacterial ability of polyethylene food packing films," Food Packaging and Shelf Life, vol. 28, Article ID 100650, 2021.

[28] Z. Xu, C. Zhang, X. Wang, and D. Liu, "Release strategies of silver ions from materials for bacterial killing," ACS Applied Bio Materials, vol. 4, no. 5, pp. 3985-3999, 2021.

[29] X.-Q. Zhao, F. Wahid, X.-J. Zhao et al., "Fabrication of amino acid-based supramolecular hydrogel with silver ions for improved antibacterial properties," Materials Letters, vol. 300, Article ID 130161, 2021.

[30] M. H. El-Rafie, A. A. Mohamed, T. I. Shaheen, and A. Hebeish, "Antimicrobial effect of silver nanoparticles produced by fungal process on cotton fabrics," Carbohydrate Polymers, vol. 80, no. 3, pp. 779-782, 2010.

[31] R. Dastjerdi and M. Montazer, "A review on the application of inorganic nano-structured materials in the modification of textiles: focus on anti-microbial properties," Colloids and Surfaces B: Biointerfaces, vol. 79, no. 1, pp. 5-18, 2010.

[32] L. Windler, M. Height, and B. Nowack, "Comparative evaluation of antimicrobials for textile applications," Environment International, vol. 53, pp. 62-73, 2013.

[33] A. Hebeish, M. E. El-Naggar, M. M. G. Fouda, M. A. Ramadan, S. S. Al-Deyab, and M. H. El-Rafie, "Highly effective antibacterial textiles containing green synthesized silver nanoparticles," Carbohydrate Polymers, vol. 86, no. 2, pp. 936-940, 2011.

[34] R. Dastjerdi, M. R. M. Mojtahedi, and A. M. Shoshtari, "Comparing the effect of three processing methods for modification of filament yarns with inorganic nanocomposite filler and their bioactivity against staphylococcus aureus," Macromolecular Research, vol. 17, no. 6, pp. 378-387, 2009.

[35] J. N. Shah, R. Padhye, and R. D. Pachauri, "Studies on UV protection and antimicrobial functionality of textiles," Journal of Natural Fibers, vol. 2021, Article ID 1932678, 12 pages, 2021.

[36] S. Andra, S. k. Balu, J. Jeevanandam, and M. Muthalagu, "Emerging nanomaterials for antibacterial textile fabrication," Naunyn-Schmiedeberg's Archives of Pharmacology, vol. 394, no. 7, pp. 1355-1382, 2021.

[37] F. Y1lmaz, "Investigating the usage of eucalyptus leaves in antibacterial finishing of textiles against Gram-positive and Gram-negative bacteria," Journal of the Textile Institute, vol. 112, no. 2, pp. 341-345, 2021. 